\title{
Postural control in blind subjects
}

\author{
Análise do controle postural em deficientes visuais \\ Antonio Vinicius Soares ${ }^{1}$, Cláudia Silva Remor de Oliveira ${ }^{2}$, Rodrigo José Knabben ${ }^{3}$, Susana Cristina Domenech ${ }^{3}$, \\ Noe Gomes Borges Junior ${ }^{3}$
}

\begin{abstract}
Objective: To analyze postural control in acquired and congenitally blind adults. Methods: A total of 40 visually impaired adults participated in the research, divided into 2 groups, 20 with acquired blindness and 20 with congenital blindness - 21 males and 19 females, mean age $35.8 \pm 10.8$. The Brazilian version of Berg Balance Scale and the motor domain of functional independence measure were utilized. Results: On Berg Balance Scale the mean for acquired blindness was $54.0 \pm 2.4$ and $54.4 \pm 2.5$ for congenitally blind subjects; on functional independence measure the mean for acquired blind group was $87.1 \pm 4.8$ and $87.3 \pm 2.3$ for congenitally blind group. Conclusion: Based upon the scale used the results suggest the ability to control posture can be developed by compensatory mechanisms and it is not affected by visual loss in congenitally and acquired blindness.
\end{abstract}

Keywords: Postural balance/physiology; Visual impairment persons; Blindness/congenital

\section{RESUMO}

Objetivo: Analisar o controle postural de indivíduos adultos com cegueira completa congênita e adquirida. Métodos: Fizeram parte da pesquisa 40 sujeitos, divididos em 2 grupos (20 com deficiência visual adquirida e 20 com deficiência visual congênita - 21 homens e 19 mulheres, média de idade $35,8 \pm 10,8)$. Os instrumentos utilizados foram a versão brasileira da Escala de Equilíbrio de Berg e o domínio motor da medida de independência funcional. Resultados: $\mathrm{Na}$ Escala de Equilíbrio de Berg a média do grupo com deficiência visual adquirida foi $54,0 \pm 2,4$ e no grupo com deficiência visual congênita foi $54,4 \pm 2,5$; na medida de independência funcional a média do grupo com deficiência visual adquirida foi $87,1 \pm 4,8$ e no grupo com deficiência visual congênita foi $87,3 \pm 2,3$. Conclusão: Baseado no instrumento utilizado, os resultados sugerem que a habilidade de controlar a postura pode ser adquirida por meio de mecanismos compensatórios, não sendo afetada pela perda visual em cegos congênitos e adquiridos.

Descritores: Equilíbrio postura//fisiologia; Portadores de deficiência visual; Cegueira/congênito

\section{INTRODUCTION}

According to the World Health Organization, blindness may be defined as any condition associated with total loss of vision, or visual acuity lower than $3 / 60$ in the better eye with the best optic correction ${ }^{(1)}$.

Postural control depends on the integration of various sensory modalities and involves the control of the position of the body in space for the double purpose of stability and orientation. The neural components essential for postural control encompass motor processes, including synergies of the muscular response; sensory processes, encompassing visual, vestibular, and somatosensory systems; and the higher level process of integration, which is vital for mapping sensations for actions and guaranteeing the aspects of anticipation and adaptation of postural control $^{(2-4)}$

As of the moment in which one of the systems involved in postural control decreases or loses its activity, in this case vision, there is a functional drop in the mechanisms involved in postural control. The visual deficit causes a delay in the response of the vestibular system and a greater variability of the center of pressure oscillation, leading to changes in equilibrium ${ }^{(3,5-7)}$.

\footnotetext{
Study carried out at Associação Catarinense para Integração dos Cegos de Florianópolis - ACIC, Florianópolis (SC), Brazil.

${ }^{1}$ Associação Catarinense de Ensino - Joinville (SC), Brazil.

${ }^{2}$ Associação Catarinense para Integração do Cego - ACIC, Florianópolis (SC), Brazil.

${ }^{3}$ Universidade do Estado de Santa Catarina - UDESC, Florianópolis (SC), Brazil.

Corresponding author: Antonio Vinicius Soares - Núcleo de Pesquisas em Neuroreabilitação (NUPEN) - Curso de Fisioterapia da Faculdade Guilherme Guimbala - Rua São José, 490 - Centro CEP 89202-010 - Joinville (SC), Brazil - Tel.: (47) 3026-4000 - E-mail: a.vini@ig.com.br

Received on: Apr 13, 2011 - Accepted on: Oct 31, 2011

Conflict of interest: none
} 
Evidence shows that cerebral plasticity of blind individuals allows areas commonly associated with processing visual information to be recruited for the development of other capacities ${ }^{(8,9)}$. Nevertheless, given the relevance of vision in posture control, there is the hypothesis that states that the absence of visual information cannot be compensated by other sensory information, which brings on postural instability ${ }^{(3)}$.

Visual loss, besides causing changes in posture control, leads to increased social dependence, limitation in the performance of daily activities, and increases the chances of falling ${ }^{(10,11)}$.

The Berg Balance Scale (BBS) is a widely used instrument for the verification of functional balance and risk of falling based on 14 tasks of daily life. It was developed by Kathy Berg in 1992 for an elderly population and patients with age-related balance deficits ${ }^{(2,12,13)}$.

Despite the wide range of information about the influence of vision on spatial orientation and posture maintenance ${ }^{(9,14-20)}$, little has been studied as to the behavior of postural control of subjects with congenital and acquired blindness.

\section{OBJECTIVE}

To analyze the postural control of adult individuals with complete congenital and acquired blindness using the BBS (Brazilian version), and to verify possible correlations with the functional independence measure (FIM).

\section{METHODS}

The study is descriptive and exploratory, and was carried out from the period of May to September of 2008 at the Associação Catarinense para Integração dos Cegos de Florianópolis (ACIC).

\section{Sample}

Forty-six subjects were selected, diagnosed with complete blindness, and divided into two groups, one with congenital visual impairment $(\mathrm{CB})$ and the other with acquired visual impairment (AB). All the subjects were submitted to prior ophthalmology assessments before entering the ACIC.

This study excluded individuals who presented with neurological lesions that are known to cause balance deficits, vestibular and/or hearing dysfunction, low vision or partial blindness, cognitive compromise, and visual impairment for less than 3 years. Of the blind subjects selected, six individuals were excluded for not corresponding to the inclusion criteria of the study.
All study participants were in training for orientation and mobility or had already concluded the rehabilitation process.

The main causes of blindness were: glaucoma, prematurity, accident, retinal disease, toxoplasmosis and old age. Other causes of visual impairment included rubella, meningitis, ocular infection, fibroplasia, measles, neurosarcoidosis, hydrocephalus, and idiopathic causes.

Table 1 shows the characterization of the sample.

Table 1. Sample characteristics

\begin{tabular}{|c|c|c|c|}
\hline Characteristics & $\begin{array}{c}\text { CONG } \\
(n=20)\end{array}$ & $\begin{array}{c}\text { ACQ } \\
(n=20)\end{array}$ & $\begin{array}{c}\text { Total } \\
(n=40)\end{array}$ \\
\hline Age in years - mean $( \pm S D)$ & $32( \pm 8.3)$ & $39( \pm 12.9)$ & $35.8( \pm 10.8)$ \\
\hline \multicolumn{4}{|l|}{ Gender - n (\%) } \\
\hline Male & $13(32.5)$ & $8(20)$ & $21(52.5)$ \\
\hline Female & $7(17.5)$ & $12(30)$ & $19(47.5)$ \\
\hline $\begin{array}{l}\text { Visual rehabilitation time in } \\
\text { years - mean }( \pm S D)\end{array}$ & $7.8( \pm 4.47)$ & $4.1( \pm 3.16)$ & $6.15( \pm 4.21)$ \\
\hline $\begin{array}{l}\text { Time of lesion in years - mean } \\
( \pm S D)\end{array}$ & $32( \pm 8.3)$ & $14.95( \pm 9.86)$ & $14.95( \pm 9.86)$ \\
\hline \multicolumn{4}{|l|}{ Physical activity - n (\%) } \\
\hline Practicing & $8(40)$ & $10(50)$ & $18(45)$ \\
\hline Not practicing & $11(55)$ & $4(20)$ & $15(37.5)$ \\
\hline Former practicing & $1(5)$ & $6(30)$ & $7(17.5)$ \\
\hline FIM -- score $( \pm$ SD) & $87( \pm 4.4)$ & $87.3( \pm 2.3)$ & $87.2( \pm 3.4)$ \\
\hline \multicolumn{4}{|l|}{ Causes of visual loss - n (\%) } \\
\hline Glaucoma & $3(15)$ & $4(20)$ & 7 (17.5) \\
\hline Prematurity & $3(15)$ & $\mathrm{N} / \mathrm{A}$ & $3(7.5)$ \\
\hline Accident & $\mathrm{N} / \mathrm{A}$ & $5(25)$ & $5(12.5)$ \\
\hline Retinal disease & $2(10)$ & $6(30)$ & $8(20)$ \\
\hline Toxoplasmosis & $3(15)$ & $\mathrm{N} / \mathrm{A}$ & $3(7,5)$ \\
\hline Age & $9(45)$ & $5(25)$ & $14(35)$ \\
\hline Others & $9(45)$ & $5(25)$ & $14(35)$ \\
\hline
\end{tabular}

n: number of cases; SD: Standard Deviation; CONG: Congenital; ACQ: Acquired ; functional FIM: functional independence measure.; N/A: not applicable

\section{Instruments}

The instruments used for the collection of data were the Brazilian version of the $\mathrm{BBS}^{(13)}$ and the motor domain of the Brazilian version of FIM ${ }^{(21)}$.

The BBS (Appendix 1) is composed of 14 tasks to be evaluated, in which each one is scored from 0 to 4 , according to the performance of the individual in executing the task. With a score of 0 , the participant is incapable of carrying out the requested task or requires a maximal degree of help to execute it, and a score of 4shows that the participant is capable of completing the task requested with no difficulties. The highest score of the test is 56 points ${ }^{(2,12,13)}$.

Due to the fact that the BBS is not specific for the visually impaired, before the test we took the patients 
through recognition of the location and the materials used by means of tactile stimulus and use of the locomotion device (cane), as well as a detailed verbal description of the tasks to be performed and an adaptation of these tasks for the study population. The instruments utilized were a stopwatch, a measuring tape, a chair with armrests and a chair without armrests, a wooden box $(51 \mathrm{~cm}$ wide, $34 \mathrm{~cm}$ deep, $20 \mathrm{~cm}$ high), and a straw hat.

Adaptations were made of two specific tasks:

- task 9: The individual under evaluation recognizes with his/her hands the object prior to performing the task. The straw hat was the object chosen due to its texture and easy identification;

- task 10: A sonorous stimulus (clapping) was chosen instead of an object to stimulate the individual under evaluation to turn around.

FIM has the objective of quantitatively evaluating the load of care demanded by a person for carrying out a series of motor and cognitive daily life tasks. The motor domain of FIM verifies the individual's performance for a set of 13 tasks, in reference to subscales of selfcare, sphincter control, transfers, and locomotion, with a maximal score of 91 . For the population under study, the use of a cane for orientation meant the loss of 1 point on the locomotion task for all participants ${ }^{(21)}$.

\section{Procedure}

The participants were previously interviewed for collection of social/demographic data, facts on associated comorbidities, the practice of physical activities or any other factor that might interfere in the physical examination of balance. Physical activity considers both present and past activities.

The individuals were initially submitted to an evaluation of posture control by means of the BBS. Next, the subjects were submitted to the assessment of functional independence by means of the motor portion of the Brazilian version of FIM.

\section{Statistical analysis}

For the statistical treatment of the quantitative data, the statistical program SPSS version 13.0 was used, and the descriptive or exploratory analysis of the data was done using means $(\overline{\mathrm{x}})$ and standard deviation (SD), when addressing numerical data, and percentual frequency $(\%)$ for categorical data. For the comparison of variables, the independent $t$ test was used to identify the differences between the two groups of participants.

Spearman's correlation was used to measure the strength of the association between posture control
(BBS) and the levels of functional independence (FIM) of both groups. The strength of the correlation among the variables was described using the coefficient of correlation ( $r$ ). The level of significance established was $\mathrm{p}<0.05$ for the entire statistical analysis.

This study was submitted to the Research Ethics Committee of the Hospital Municipal São José, Joinville (SC), according to Regulating Directives and Guidelines of the National Health Council (National Resolutions 196/96 and 251/97), with Protocol \# 08045. The collection of data was performed with prior authorization of the Coordination of ACIC and all individuals signed the Informed Consent Form and received the same form in Braille.

\section{RESULTS}

The average time of lesion was 14.95 years for the $A B$ group, and 32 years for the CB group.

The results obtained in the evaluation of posture control by means of the BBS showed a high overall mean for both groups $(\overline{\mathrm{x}}=54.20 \pm 2.6)$. Among the 20 participants of the $\mathrm{CB}$ group, the minimal score on the scale was 49 and the maximal was 56 points $(\overline{\mathrm{x}}=54 \pm 2.42)$. For the $\mathrm{AB}$ group, the minimal score obtained on the scale was 47 and the maximal was 56 points $(\overline{\mathrm{x}}=54.4 \pm 2.54)$. Both groups showed similar high overall means in the test results, and $50 \%$ of the sample displayed a maximal score of 56 points on the BBS. There was no statistically significant difference in posture control when the two groups of blind individuals were compared $(t=0.509, \mathrm{p}>0.05)$.

In analyzing the strength of the correlation of posture control by means of the BBS with the results of functional independence by means of the motor domain of FIM, unlike what was expected, the findings revealed a non significant correlation $(\mathrm{r}=0.274, \mathrm{p}>0.05)$. Figure 1 shows the performance on BBS and FIM for both groups.

When analyzing the relationship of time of lesion with the performance on the BBS, it was noted that

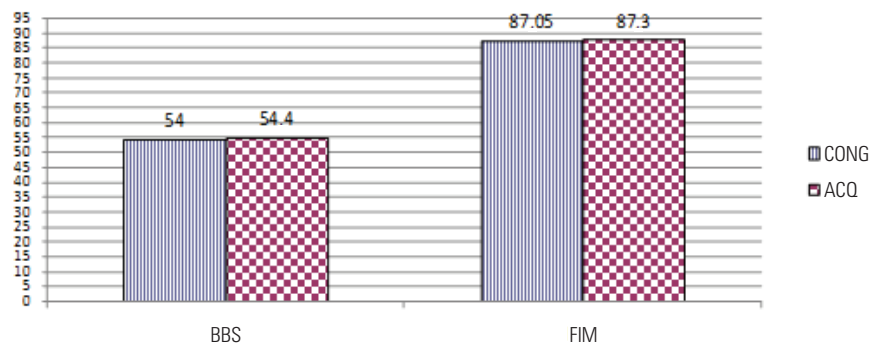

BBS: Berg Balance Scale

FIM: functional independence measure

CONG: Congenital; ACQ: Acquired

Figure 1. Performance in BBS and FIM in both groups 
the group with time of lesion of more than 10 years had a better performance on BBS $(\overline{\mathrm{x}}=54.45 \pm 2.25)$ than the individuals with visual impairment for less than ten years $(\overline{\mathrm{x}}=53 \pm 3.26)$, albeit without statistical significance $(t=1.439, \mathrm{p}>0.05)$. The results suggest that the time of blindness did not exert a direct influence on the posture control of the visually impaired with lesions for more than two years.

In the same way, there was no difference when the posture control of the individuals was compared to a rehabilitation time superior to and inferior to 2 years. Despite the group with rehabilitation time of more than two years having shown the best results on the BBS $(\overline{\mathrm{x}}=54.52 \pm 2.01)$ relative to individuals who had been in rehabilitation for a shorter time $(\overline{\mathrm{x}}=53.57 \pm 3.83)$, the difference was not statistically significant $(t=0.745, \mathrm{p}>0.05)$.

When analyzing the performance of activities of the BBS, among the 14 tasks that make up the scale, there was greater difficulty for the participants in four specific tasks: reaching forward (Task 8), turning $360^{\circ}$ (Task 11), placing one foot in front of the other (Task 13), and one-foot support (Task 14). In spite of this, the average score for each task was high, and 30 participants attained the maximal score on Tasks 8 and 13; 35 participants reached maximal score on Task 11, and 23 participants had the maximal score on Task 14. The means and percentages of the tasks may be seen on table 2 .

Table 2. Performance of more complex tasks in Berg Balance Scale

\begin{tabular}{lcc}
\hline Task & Mean score & \% maximum score (4) \\
\hline $\begin{array}{l}\text { Number 8: To reach forward with } \\
\text { outstretched arms }\end{array}$ & 3.73 & $75(\mathrm{n}=30)$ \\
$\begin{array}{l}\text { Number 11: To turn } 360^{\circ} \\
\text { Number 13: To remain standing with }\end{array}$ & 3.78 & $87.5(\mathrm{n}=35)$ \\
$\begin{array}{l}\text { one foot in front of the other } \\
\text { Number 14: To remain standing on } \\
\text { one foot }\end{array}$ & 3.08 & $75(\mathrm{n}=30)$ \\
\hline
\end{tabular}

There was no statistically significant difference in the tasks when the performance of the two groups is compared (Task $8 t=0.936, \mathrm{p}>0.05$; Task 11 $t=0.252, \mathrm{p}>0.05$; Task $13 t=-0.936, \mathrm{p}>0.05$; Task $14 t=-1.436, \mathrm{p}>0.05)$.

\section{DISCUSSION}

Visual information is very important for balance control and precision of the velocity of movement of objects and body segments, as well as for the time and exactness of the motor reaction, and its decrease could lead to postural maladjustment and/or disharmony ${ }^{(22)}$.
However, the anatomical separation of the systems involved in postural control suggests that the nervous system has the ability to discreetly change the primary source necessary for posture adjustment. In the absence of the visual system, the dominance passes to the vestibular and somatossensorial system, a fact that explains posture control in the visually impaired ${ }^{(23,24)}$.

It is a known fact that the BBS was created to evaluate balance and risk of falling in elderly persons, with a maximal score of 56. A score of 0 to 20 is related to poor equilibrium, and from 40 to 56 to good equilibrium ${ }^{(2,12,13,25)}$.

The present study analyzed the posture control of individuals with congenital and acquired blindness. The results obtained in this study, by means of the BBS, showed that blind individuals with a time of lesion of more than three years display good posture control. The subjects analyzed reached scores close to the maximum, which suggests that blind individuals present with compensatory mechanisms that guarantee posture control.

In a study using a more sensitive instrument for analysis of equilibrium (force platform), Nakata and Yabe(17) investigated the velocity of postural adjustment after displacement on an unstable platform comparing blind and seeing individuals. The results of the investigation suggest that the capacity to control balance with automatic posture responses is not affected by the loss of vision in congenitally blind persons when compared to those with sight.

In agreement with findings in literature, in comparing posture control of the $\mathrm{CB}$ and $\mathrm{AB}$ groups, we noted that there is no statistically significant difference between the two groups. All the individuals participating in the study had a time of lesion of more than 3 years, and despite this variable not showing a statistically significant influence on posture control, the similar results in both groups reinforced the perception that blind individuals develop postural adjustment mechanisms after the period of adaptation of the deficiency, so as to allow posture maintenance ${ }^{(3,26)}$.

In the present study, the average time of lesion for the $\mathrm{AB}$ group was 14.95 years, a factor that may also explain the similar results in both groups, as a result of the period of adaptation to loss of visual information. Additionally, all study participants were undergoing or had already completed the process of visual rehabilitation, including orientation and mobility.

Barry et al. ${ }^{(6)}$, when studying vestibular function in congenitally blind individuals by means of cerebral cortex stimulation, found that blind persons are less able to use spatial mechanisms during vestibular stimulation, but when submitted to the activity of 
spatial orientation, can increment the vestibular response.

Schmid et al. ${ }^{(3)}$, in researching the performance of static and dynamic equilibrium in subjects with acquired and congenital blindness using the force platform, found that both the groups of visually impaired individuals showed similar responses, suggesting the prolonged absence of visual information promotes strategies for maintenance of postural control.

Accordingly, Stones and Kozma ${ }^{(26)}$, when evaluating equilibrium in 22 blind individuals found no differences between the group with congenital blindness versus the group with acquired blindness. In this study, a minimal difference in balance was found in the comparison between blind and seeing individuals.

Rougier and Farenc ${ }^{(27)}$ in researching the effects of loss of vision on posture maintenance using the force platform found that blind individuals have a decrease in movement of the center of pressure and the center of gravity, allowing maintenance of postural control. In the above mentioned studies, even though the force platforms were used for analysis of equilibrium, the findings were similar to those of the clinical instrument used in this investigation.

Nevertheless, we should consider that the BBS was initially developed for analysis of balance and risk of falling in the elderly population and not to evaluate equilibrium in adult blind individuals. No scientific record was found on the utilization of the scale in the blind population. One should also consider the small sample used, which does not allow us to widely infer the results found.

\section{CONCLUSIONS}

Based on the findings of this research, the capacity to maintain postural control is not affected by loss of vision in individuals who are congenitally blind and those who acquired blindness with time of lesion of more than 3 years and are independent in daily living.

There was no significant difference between the groups, suggesting that time of lesion, as well as the rehabilitation process, may stimulate compensatory mechanisms resulting from cerebral plasticity, in such a way as to guarantee postural control in the blind population. The comparison with seeing subjects was not the objective of this study.

Future studies that include individuals with a short time of lesion and involve seeing subjects in a control group, as well as the comparison with biomechanical instrumentation are necessary in order to confirm the applicability of the scale used for analysis of postural control in the blind.

\section{REFERENCES}

1. World Health Organization. Strategies for the prevention of blindness in national programmes; a primary healthy care approach. 2nd ed. Geneva: World Health Organization; 1997.

2. Shumway-Cook A, Woollacott MH. Controle motor: teoria e aplicações práticas. 2a ed. São Paulo: Manole; 2002.

3. Schmid M, Nardone A, De Nunzio AM, Schmid M, Schieppati M. Equilibrium during static and dynamic tasks in blind subjects: no evidence of cross-modal plasticity. Brain. 2007;130(Pt 8):2097-107.

4. Peterka RJ. Sensorimotor integration in human postural control. J Neurophysiol. 2002;88(3):1097-118.

5. Oliveira DN, Barreto RR. Avaliação do equilíbrio estático em deficientes visuais adquiridos. Rev Neuroci. 2005;13(3):122 -7.

6. Seemungal BM, Glasauer S, Gresty MA, Bronstein AM. Vestibular perception and navigation in the congenitally blind. J Neurophysiol. 2007;97(6):4341-56.

7. Rougier P. Visual feedback induces opposite effects on elementary centre of gravity and centre of pressure minus centre of gravity motions in undisturbed upright stance. Clin Biomech (Bristol, Avon). 2003;18(4):341-9.

8. Bavelier D, Neville HJ. Cross-modal plasticity: where and how? Nat Rev Neurosci. 2002;3(6):443-52.

9. Théoret H, Merabet L, Pascual-Leone A. Behavioral and neuroplastic changes in the blind: evidence for functionally relevant cross-modal interactions. J Physiol Paris. 2004;98(1-3):221-33.

10. Taylor HR. The economics of vision loss. Int Congr Ser. 2005;1282:453-7.

11. Varma R, Wu J, Chong K, Azen SP, Hays RD; Los Angeles Latino Eye Study Group. Impact of severity and bilaterality of visual impairment on health-related quality of life. Ophthalmology. 2006;113(10):1846-53.

12. Berg KO, Maki BE, Williams JI, Holliday PJ, Wood-Dauphinee SL. Clinical and laboratory measures of postural balance in an elderly population. Arch Phys Med Rehabil. 1992;73(11):1073-80.

13. Miyamoto ST, Lombardi Junior I, Berg KO, Ramos LR, Natour J. Brazilian version of the Berg balance scale. Braz J Med Biol Res. 2004;37(9):1411-21.

14. Juodzbaliene $V$, Muckus $K$. The influence of the degree of visual impairment on psychomotor reaction and equilibrium maintenance of adolescents. Medicina (Kaunas). 2006;42(1):49-56.

15. Marigold DS, Eng JJ. The relationship of asymmetric weight-bearing with postural sway and visual reliance in stroke. Gait Posture. 2006;23(2):249-55.

16. Redfern MS, Yardley L, Bronstein AM. Visual influences on balance. J Anxiety Disord. 2001;15(1-2):81-94.

17. Nakata $H$, Yabe K. Automatic postural response systems in individuals with congenital total blindness. Gait Posture. 2001;14(1):36-43.

18. Wade $M G$, Jones $G$. The role of vision and spatial orientation in the maintenance of posture. Phys Ther. 1997;77(6):619-28.

19. Kandel ER, Schwartz JH, Jessell TM. Fundamentos da neurociência e do comportamento. Rio de Janeiro: Guanabara Koogan; 1997.

20.Dijkstra TM, Schöner G, Gielen CC. Temporal stability of the actionperception cycle for postural control in a moving visual environment. Exp Brain Res. 1994;97(3):477-86.

21. Ribeiro M, Miyazaki MH, Jucá SS, Sakamoto H, Pinto PP, Battistella LR. Validação da versão brasileira da medida de independência funcional. Acta Fisiátr. 2004;11(2):72-6.

22. Viel E. A Marchahumana, a corrida e o salto: biomecânica, investigações, normase disfunções. São Paulo: Manole; 2001.

23. McCollum G, Shupert CL, Nashner LM. Organizing sensory information for postural control in altered sensory environments. J Theor Biol. 1996;180(3):257-70. 
24. Maurer C, Mergner T, Bolha B, Hlavacka F. Vestibular, visual, and somatosensory contributions to human control of upright stance. Neurosci Lett. 2000;281(2-3):99-102.

25. Berg KO, Wood-Dauphinee SL, Williams Jl, Maki B. Measuring balance in the elderly: validation of an instrument. Can J Public Health. 1992;83(Suppl 2):S7-11.
26. Stones MJ, Kozma A. Balance and age in the sighted and blind. Arch Phys Med Rehabil. 1987;68(2):85-9.

27. Rougier $P$, Farenc I. Adaptative effects of loss of vision on upright undisturbed stance. Brain Res. 2000;871(2):165-74.

Appendix 1. Brazilian version of the Berg Balance Scale

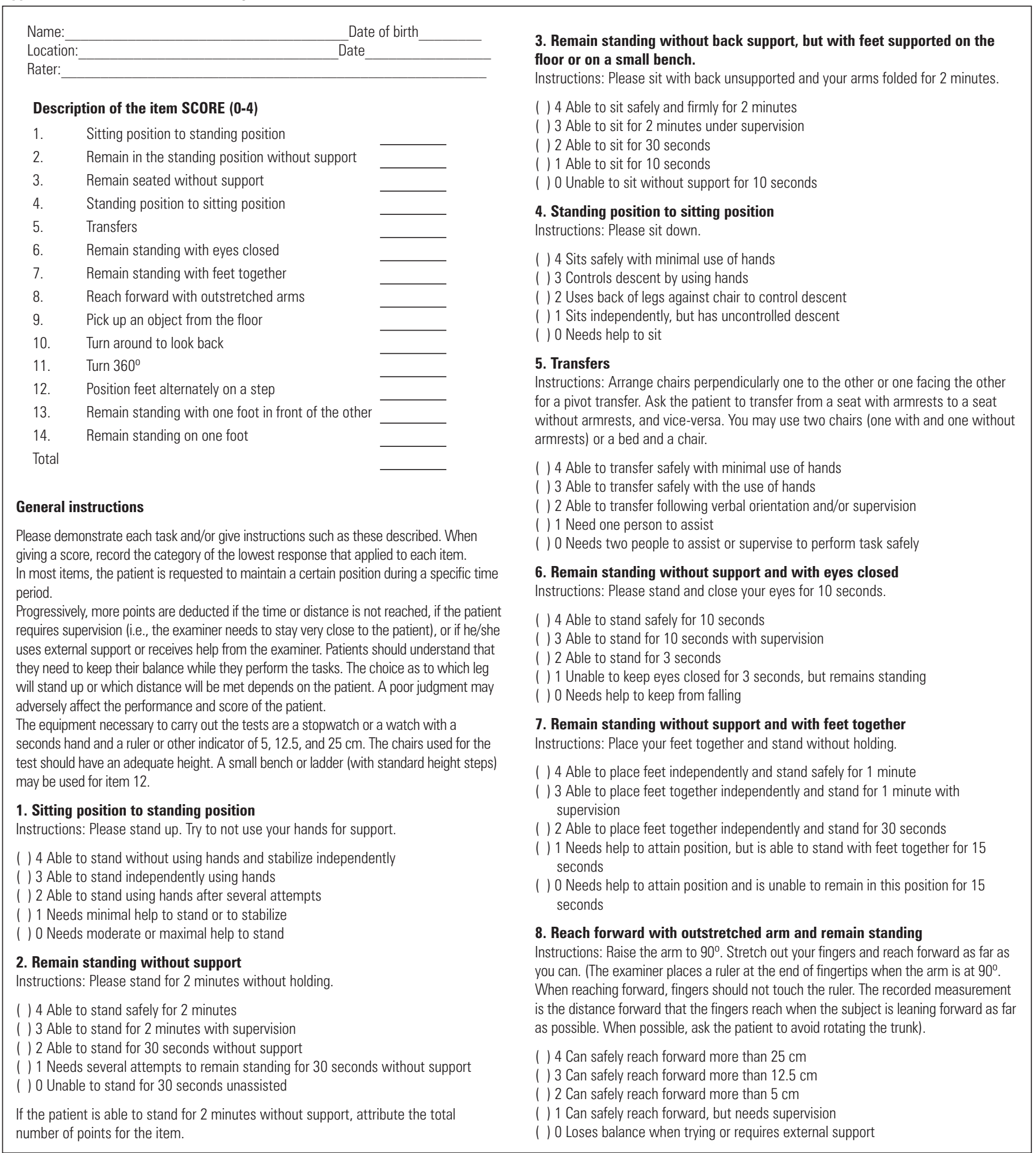


Appendix 1. Continuation

\section{Pick up an object from the floor from a standing position} Instructions: Pick up the shoe/slipper that is in front of your feet.

( ) 4 Able to pick up slipper easily and safely

( ) 3 Able to pick up slipper, but needs supervision

( ) 2 Unable to pick up, but reaches $2.5 \mathrm{~cm}$ from the slipper and keeps balance independently

( ) 1 Unable to pick up and needs supervision while trying

( ) 0 Unable to try or needs help to keep from losing balance or falling

10. Turn and look back over the right and left shoulder while remaining in the standing position

Instructions: Turn to look directly behind you over your left shoulder without taking your feet off the floor. Do the same over your right shoulder.

(The examiner may place an object directly behind the patient to stimulate movement)

( ) 4 Looks behind from both sides with good weight shift

( ) 3 Looks behind from one side only; the other side demonstrates less weight shift

( ) 2 Turns sideways only, but maintains balance

( ) 1 Needs supervision to turn

( ) 0 Needs help to keep from losing balance of falling

\section{Turn 360 degrees}

Instructions: Turn completely around yourself in a full circle. Pause. Turn completely around yourself in the other direction.

( ) 4 Able to turn 360 degrees safely in 4 seconds or less

( ) 3 Able to turn 360 degrees safely only to one side in 4 seconds or less

( ) 2 Able to turn 360 degrees safely, but slowly

( ) 1 Needs close supervision or verbal orientation

( ) 0 Needs assistance while turning
12. Position feet alternately on the step or bench while remaining in the standing position without support

Instructions: Touch each foot alternately to the step/bench. Continue until each foot has touched the step/bench four times.

( ) 4 Able to stand independently and safely, completing 8 steps/movements in 20 seconds

( ) 3 Able to stand independently and complete 8 steps/movements in more than 20 seconds

( ) 2 Able to complete 4 steps/movements without help

( ) 1 Able to complete more than 2 steps/movements with minimal help

( ) 0 Unable to try, or needs help to keep from falling

\section{Remain standing without support with one foot in front of the other.} Instructions: (demonstrate to the patient) Place one foot directly in front of the other along the same line; if you feel that you cannot do this, place your foot forward ahead and slightly to the side of the other foot.

() 4 Able to place one foot immediately in front of the other independently and hold for 30 seconds

( ) 3 Able to place one foot slightly ahead and to the side of the other foot, independently, and hold for 30 seconds

( ) 2 Able to take a small step, independently, and hold for 30 seconds

( ) 1 Needs help to take the step, but holds for 15 seconds

( ) 0 Loses balance when trying to take a step or stand

\section{Remain standing on one leg}

Instructions: Stand on one leg as long as you can without hold.

( ) 4 Able to lift one leg independently and hold for more than 10 seconds

( ) 3 Able to lift one leg independently and hold for $5-10$ seconds

( ) 2 Able to lift one leg independently and hold for more than 3 seconds

( ) 1 Tries to lift one leg, but is unable to hold for 3 seconds, however can remain standing independently

( ) 0 Unable to try, or needs help to keep from falling

( ) Total score (maximum $=56$ ). 